\title{
Pengaruh Metode Shared Medical Appointments Terhadap Perbaikan Kontrol Metabolik Pasien Diabetes Melitus Tipe-1 pada Anak dan Remaja
}

Faisal, Novina Andriana

Departemen/KSM Ilmu Kesehatan Anak Fakultas Kedokteran, Universitas Padjadjaran/Rumah Sakit Dr. Hasan Sadikin, Bandung

Latar belakang. Metode sharing medical appointment (SMAs) merupakan program intervensi edukasi yang melibatkan peran keluarga, pengalaman sesama pasien, motivasi, dukungan komunikasi dari dokter dan edukator untuk pasien dengan penyakit kronik.

Tujuan. Mengetahui keefektifan metode SMAs terhadap perbaikan kontrol metabolik DM tipe-1 pada anak dan remaja.

Metode. Penelitian analitik dengan rancangan randomized controlled trial untuk membandingkan kontrol metabolik kelompok SMAs berdurasi 60 menit setiap pertemuan dengan kelompok individual. Data demografi, klinis, dan HbA1C dikumpulkan dan dianalisis serta dilakukan uji $\mathrm{T}$ untuk membandingkan perbedaan rerata kadar HbA1C dan uji repeated ANOVA untuk membandingkan rerata sekuensial HbA1C pada dua kelompok dengan nilai kemaknaan $\mathrm{p}<0,05$.

Hasil. Masing-masing 20 subjek kelompok SMAs dan kelompok IMA disertakan dalam penelitian dengan rerata kadar HbA1C berturut-turut untuk kelompok SMAs adalah $9,73 \pm 1,8$ pada bulan ke- $0,8,7 \pm 1,3$ bulan ke- 3 dan $8,54 \pm 0,7$ pada bulan ke-6, lebih baik dibandingkan pada kelompok IMA, yaitu 9,57 $\pm 1,6$ pada bulan ke- $0,9,26 \pm 1,1$ bulan ke- 3 dan 9,86 $\pm 1,2$ bulan ke- 6 . Perbedaan rerata HbA1C didapatkan pada perbandingan bulan ke-0 vs ke-6 [p<0,05 IK95\%: 1,32 (0,69-1,95)]. Pada kelompok SMAs didapatkan perbedaan rerata HbA1C antara bulan ke-0 vs ke-3 ( $<<0,05)$ dan bulan ke-0 vs ke-6 ( $<<0,05)$, tetapi tidak berbeda pada bulan ke-3 vs ke-6 ( $\mathrm{p}>0,05)$.

Kesimpulan. Metode SMAs dengan durasi 3 bulan efektif dalam memperbaiki kontrol metabolik penderita DM tipe-1 pada anak dan remaja. Sari Pediatri 2018;20(3):138-45

Kata kunci: DM tipe-1, anak dan remaja, shared medical appointment, kontrol metabolik

\section{Effect of Shared Medical Appointments on Metabolic Control Improvement in Children and Adolescent with Type 1 Diabetes}

Faisal, Novina Andriana

Department of Child Health, Faculty of Medicine, Universitas Padjajaran/Hasan Sadikin General Hospital Bandung

Background. Shared medical appointments (SMAs) is an educational intervention program that involves family's roles, other people's experiences, motivations and communication support from both doctors and educators of chronic diseases.

Objective. To determine the effectiveness of SMAs method to improve metabolic control in children and adolescents with Type 1 Diabetes.

Methods. A randomized controlled trial design comparing metabolic control individual medical appointment (IMA) as control group with six 60-minute SMAs (intervention group) sessions. Demographic, clinical and glycosylated haemoglobin measures were obtained from all participants at baseline, 3 and 6 months. Statistical analysis was performed using T-test to compare the mean difference of $\mathrm{HbA} 1 \mathrm{C}$ and repeated ANOVA test to compare the sequences HbA1C in both groups.

Result. Forty-three participants were randomized into the 2 study groups with $93 \%$ completion rate $(\mathrm{n}=20$ SMAs, $\mathrm{n}=20$ IMA). The consecutive HbA1C levels for the SMAs group were $9.73 \pm 1.8$ (at baseline) $8.7 \pm 1.3$ (at 3 months) and $8.54 \pm 0.7$ (at 6 months). These results were better than the IMA group, which were $9.57 \pm 1.6$ (baseline), $9.26 \pm 1.1$ (3 months) and $9.86 \pm 1.2$ (6 months). A significant mean difference of HbA1c was obtained from baseline vs month 6 [p <0.05 CI 95\% 1.32 (0.69-1.95)]. In the SMAs group, the mean differences of HbA1C baseline vs month $3(\mathrm{p}<0,05)$ and baseline vs month $6(\mathrm{p}<0,05)$ were significant. No significant difference was found by comparing month 3 vs month 6 ( $p>0.05$ ).

Conclusion. A 3-month SMAs method is effective in improving the metabolic control of children and adolescents with T1D. Sari Pediatri 2018;20(3):138-45

Keywords: type 1 diabetes, children and adolescents, shared medical appointments, metabolic control

Alamat korespondensi: Faisal. Departemen/Kelompok Staf Medis Ilmu Kesehatan Anak Fakultas Kedokteran Universitas Padjadjaran/ Rumah Sakit dr. Hasan Sadikin Jl. Pasteur no 38 Bandung 40161. E-mail: faisal@unpad.ac.id 


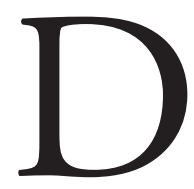
iabetes melitus (DM) merupakan kelainan sistemik akibat gangguan dari metabolisme glukosa yang ditandai dengan adanya hiperglikemia kronik. ${ }^{1,2}$ Jumlah kasus DM di dunia semakin bertambah setiap tahunnya. Insiden DM tipe-1 bervariasi di berbagai negara dengan insiden tertinggi adalah di Finlandia sejumlah 43/100.000 orang dan terendah di Jepang sebesar 1,5-2/100.000 untuk usia kurang dari 15 tahun. ${ }^{2}$ Diyakini dari 80.0000 kasus baru DM anak setiap tahun adalah tipe 1 di seluruh dunia. ${ }^{2}$ Saat ini, data register unit kelompok kerja endokrinologi anak Ikatan Dokter Anak Indonesia tercatat sejumlah 1021 anak dan remaja di seluruh Indonesia yang menderita DM tipe-1. ${ }^{3}$ Jumlah ini belum menunjukkan angka yang sebenarnya karena sebagian kasus tidak terdata dengan baik atau bahkan tidak terdiagnosis. ${ }^{2-3}$

Upaya komprehensif dalam manajemen DM tipe-1 untuk mencapai kontrol metabolik yang baik meliputi pemberian insulin, pengaturan nutrisi, olahraga dan edukasi dengan dukungan pemantauan gula darah (GD) mandiri secara berkala., ${ }^{2,-10}$ Edukasi mempunyai peran yang penting untuk menyampaikan informasi cara pemberian insulin rutin, pengaturan makan, olahraga dan pemantauan GD. ${ }^{5}$ Saat ini, metode edukasi yang dilakukan dengan rutin dan rinci kepada pasien atau orang tua pasien dilakukan pada saat kunjungan ke rumah sakit secara individual., 511 Kelemahan edukasi secara individu adalah adanya sifat yang tertutup pada anak dalam menyampaikan permasalahannya kepada dokter, kesenjangan usia dokter dan pasien anak, suasana formal di rumah sakit serta dominasi orang tua pada saat kunjungan pasien DM. ${ }^{11-12}$ Oleh karena itu, perlu adanya kegiatan edukasi DM cara lain yang terstruktur dan terjadwal dengan metode yang tepat agar penderita DM dan keluarga dapat konsisten dalam upaya penanganan penyakitnya secara mandiri dan komprehensif. ${ }^{11-14}$

Metode edukasi yang dikembangkan di beberapa negara pada pasien dengan penyakit kronik adalah dengan mengadopsi metode shared medical appointments (SMAs). SMAs adalah kunjungan berkala satu kelompok pasien yang mempunyai karakteristik penyakit individual yang sama, dengan konsep saling berinteraksi, bercerita, dan mendengar serta belajar satu sama lain dari masing-masing kasus. ${ }^{11,14-15}$ Metode SMAs dikembangkan untuk memperbaiki akses pada pelayanan kesehatan, pemanfaatan dukungan sesama penyandang penyakit kronik, mengurangi biaya kesehatan dan meningkatkan kepuasan dalam tata laksana penyakit kronik pada pasien dewasa di beberapa tempat. ${ }^{13-17}$ Pada usia anak dan remaja, metode ini belum banyak dilakukan. Salah satunya adalah yang dilakukan oleh Mejino $\mathrm{dkk}^{14}$ di Belanda dengan subjek anak dan remaja yang menderita DM tipe-1. Namun, hingga saat ini di Indonesia belum pernah dilakukan penelitian tentang penerapan metode SMAs untuk kasus DM tipe-1 pada anak dan remaja. Oleh karena itu, penelitian ini dilakukan dengan tujuan untuk mengetahui kelayakan dan keefektifan metode shared medical appointment terhadap perbaikan kontrol metabolik DM tipe-1 pada anak dan remaja.

\section{Metode}

Penelitian analitik dengan rancangan randomized controlled trial dilakukan pada subjek penelitian yang diambil dengan pendekatan purposive sampling. Kriteria inklusi adalah pasien DM tipe-1 berusia 5-14 tahun, bersedia mengikuti penelitian dengan menandatangani persetujuan (informed consent), menggunakan insulin dengan regimen konvensional split mix atau intensif basal bolus, dan bagi anak yang berusia $<12$ tahun bersedia didampingi oleh orang tual wali. Kriteria eksklusi adalah pasien yang tidak datang secara rutin ke poli endokrin anak rumah sakit dan menggunakan pompa insulin. Penelitian dilakukan di Poliklinik Endokrin Anak RSUP dr. Hasan Sadikin pada 1 Juni 2016 sampai dengan 30 April 2017.

Pada saat kunjungan ke poliklinik, orangtua dan pasien diberi penjelasan tentang penelitian dan setelah mendapat informed consent dilanjutkan pencatatan karakteristik umum, anamnesis riwayat penyakit, pemeriksaan fisis, dan pengambilan darah untuk pemeriksaan kadar HbA1C. Subjek penelitian dibagi dua kelompok, kelompok pertama dinamakan grup shared medical appointments (SMAs) dan sebagai kontrol adalah kelompok individual medical appointment (IMA).

Pada kelompok pertama dilakukan metode SMAs enam kali pertemuan, dengan interval satu kali setiap bulan berdurasi 60 menit tiap pertemuan. Pada setiap pertemuan ada satu orang dokter endokrinologi anak yang menjadi fasilitator. Pada kelompok dua, subjek mendapat edukasi secara individual oleh dokter sesuai dengan standar pelayanan anak sebanyak enam kali, interval satu kali setiap bulan. Sebagai parameter kontrol metabolik dilakukan pemeriksaan HbA1C 
menggunakan prosedur immunoturbidimetric assay yang telah diuji dan divalidasi setara dengan highperformance liquid chromatography (HPLC) kepada seluruh subjek yang dilakukan pada awal penelitian, akhir bulan ke-3, dan ke-6. Seluruh data yang diperoleh akan diolah secara statistik dengan menggunakan piranti lunak SPSS version 18 for Windows. Analisis statistik uji $\mathrm{T}$ dilakukan untuk membandingkan perbedaan rerata kadar $\mathrm{HbA1C}$ sebelum dan sesudah metode SMAs dan uji repeated ANOVA untuk melihat perbedaan $\mathrm{HbA1C}$ pada bulan ke-0 (baseline), 3, dan 6 pada dua kelompok $(\mathrm{p}<0,05)$. Penelitian ini sudah mendapat izin Komite Etik Penelitian FK Unpad dengan nomor 260/UN6.C1.3.2/KEPK/PN/2016 yang dikeluarkan di Bandung pada tanggal 24 Maret 2016.

\section{Hasil}

Didapatkan 68 anak DM tipe-1 yang berobat jalan di Poliklinik Endokrin anak RSUP dr. Hasan Sadikin Bandung dan dari jumlah tersebut terdapat 43 subjek yang bersedia mengikuti penelitian. Dua subjek dieksklusi karena tidak hadir pada pertemuan kedua dan satu subjek pindah rumah. Subjek dibagi dalam kelompok SMAs dan kelompok IMA masing-masing terdiri dari 20 subjek. Terdapat 6 laki-laki dan 14 perempuan pada kelompok SMAs, sedangkan pada kelompok IMA masing-masing 10 anak laki-laki dan perempuan. Berdasarkan penggolongan usia pada 2 kelompok, subjek termuda berusia 4 tahun dan tertua 14 tahun. Sebagian besar subjek adalah anak berusia 8-12 tahun baik pada kelompok SMAs (12 orang) ataupun kelompok kontrol (9 orang). Usia saat diagnosis didapatkan terbanyak pada usia 8-12 tahun pada kelompok SMAs sejumlah 10 orang dan pada kelompok IMA 8 orang. Durasi DM terbanyak adalah 1-5 tahun pada 14 subjek kelompok SMAs dan 15 subjek pada kelompok IMA (Tabel 1).

Pada telaah klinis didapatkan 75\% pada subjek kelompok SMAs mengalami ketoasidosis diabetikum (KAD) saat pertama kali terdiagnosis DM dan $60 \%$ pada kelompok IMA. Regimen insulin yang digunakan oleh kedua kelompok tidak berbeda, yaitu $50 \%$ pada kelompok SMAs dan 60\% pada kelompok IMA menggunakan regimen konvensional splitmix dengan insulin campuran kerja cepat dan menengah. Sementara sisa 50\% pada kelompok SMAs dan 40\% pada IMA menggunakan regimen basal bolus dengan insulin kerja panjang dan insulin kerja cepat.

Pada riwayat penghentian insulin didapatkan 3 subjek pada kelompok SMAs pernah menghentikan pemberian insulin, tetapi pada kelompok IMA hanya

Tabel 1. Karakteristik umum subjek penelitian

\begin{tabular}{lcc}
\hline Karakteristik & $\begin{array}{c}\text { Grup SMAs } \\
(\mathrm{n}=20)\end{array}$ & $\begin{array}{c}\text { Grup IMA } \\
(\mathrm{n}=20)\end{array}$ \\
\hline Jenis kelamin (\%) & & \\
Laki-laki & $6(30)$ & $10(50)$ \\
Perempuan & $14(70)$ & $10(50)$ \\
Usia (tahun) & & \\
Rerata & $10,88 \pm 2,2$ & $11,12 \pm 2,6$ \\
$\quad$ Minimum & 4 & 5 \\
Maksimum & 13 & 14 \\
Usia saat diagnosis (tahun) & & \\
Rerata & $8,35 \pm 0,60$ & $9,07 \pm 0,59$ \\
Minimum & 2,59 & 3 \\
Maksimum & 12,5 & 13 \\
Durasi DM (tahun) & & \\
Rerata & $2,52 \pm 0,45$ & $1,85 \pm 0,28$ \\
Minimum & 0,5 & 0,5 \\
Maksimum & 8 & 4,5 \\
\hline Keng
\end{tabular}

Keterangan: analisis berdasarkan uji chi-kuadrat bermakna bila $\mathrm{p}<0,05$ 
terdapat 1 subjek saja. Riwayat pengobatan alternatif juga didapatkan pada 3 subjek kelompok SMAs dan 4 subjek pada kelompok IMA (Tabel 2).

Hampir seluruh subjek memiliki alat glukometer dan melakukan pencatatan gula darah harian (19 subjek pada kelompok SMAs dan 17 subjek pada kelompok IMA). Frekuensi pencatatan gula darah harian dilakukan paling sering adalah 2 kali perhari, yaitu didapatkan pada 16 subjek di kelompok SMAs dan 13 subjek pada kelompok IMA. Hanya 4 subjek pada kelompok SMAs dan 3 subjek pada kelompok IMA (20\% dan $15 \%$ ) yang mempunyai riwayat DM pada orang tua.

Sebagai parameter kontrol metabolik diperiksa kadar HbA1C yang diambil saat baseline (bulan ke-0), kemudian setelah mendapat perlakuan metode SMAs pada kelompok SMAs diperiksa ulang kadar HbA1C bulan ke-3 dan ke-6. Kadar HbA1C berturut-turut untuk kelompok SMAs adalah 9,73 \pm 1.8 pada baseline, $8,70 \pm 1,3$ bulan ke-3 dan $8,54 \pm 0,7$ pada bulan ke- 6 . Hasil ini lebih rendah dibandingkan pada kelompok IMA, yaitu 9,57 $\pm 1,6$ pada baseline, 9,26 $\pm 1,1$ bulan ke-3 dan 9,86 $\pm 1,2$ pada bulan ke-6 (Gambar 1).
Pada perbandingan rerata $\mathrm{HbA1C}$ bulan ke-0 dengan bulan ke-3 antara kelompok SMAs dan IMA tidak didapatkan perbedaan yang bermakna $(p>0,05)$. Rerata HbA1C bulan ke-6 antara dua kelompok didapatkan perbedaan yang bermakna $(\mathrm{p}<0,05)$ dengan interval kepercayaan 95\% sebesar 1,32 (0,69-1,95).

Pada uji repeated ANOVA menunjukkan pada kelompok SMAs terdapat perbedaan yang bermakna rerata $\mathrm{HbA1C}$ antara bulan ke-0 dengan bulan ke-3 $(\mathrm{p}=0,002)$ dan rerata $\mathrm{HbA1C}$ bulan ke- 0 dengan bulan ke-6 $(\mathrm{p}=0,005)$. Namun, perbandingan rerata HbA1C antara bulan ke-3 dengan bulan ke- 6 tidak didapatkan perbedaan yang bermakna $(p>0,05)$. Sementara itu, pada kelompok IMA tidak didapatkan perbedaan yang bermakna antara rerata $\mathrm{HbA1C}$ bulan ke-0 dengan bulan ke-3, bulan ke-0 dengan bulan ke-6, dan bulan ke-3 dengan ke-6 (Tabel 4).

\section{Pembahasan}

Tidak ada perbedaan gender untuk kasus DM di dunia walaupun pada beberapa kasus penyakit otoimun lebih

Tabel 2. Karakteristik klinis subjek penelitian

\begin{tabular}{lcc}
\hline & Grup SMA & Grup IMA \\
\cline { 2 - 3 } Karakteristik klinis & $(\mathrm{n}=20)$ & $(\mathrm{n}=20)$ \\
\hline Riwayat KAD saat diagnosis (\%) & $15(75)$ & $12(60)$ \\
Ya & $5(25)$ & $8(40)$ \\
Tidak & & \\
Regimen (\%) & $10(50)$ & $12(60)$ \\
Split mix & $10(50)$ & $8(40)$ \\
Basal Bolus & & 2 \\
Pemantauan GDS / hari & 3 & 13 \\
1 kali & 16 & 5 \\
2 kali & 1 & 1 \\
$>2$ kali & 3 & 19 \\
Riwayat penghentian insulin & 17 & 4 \\
Ya & & 16 \\
Tidak & 3 & 3 \\
Riwayat pengobatan alternatif & 17 & 17 \\
Ya & & $1,18 \pm 0,27$ \\
Tidak & 4 & \\
Riwayat DM pada keluarga & 16 & \\
Ya & $1,09 \pm 0,37$ & \\
Tidak & & \\
Dosis total harian insulin &
\end{tabular}


Faisal dkk: Pengaruh metode SMAs terhadap perbaikan kontrol metabolik DM Tipe-1 pada anak dan remaja

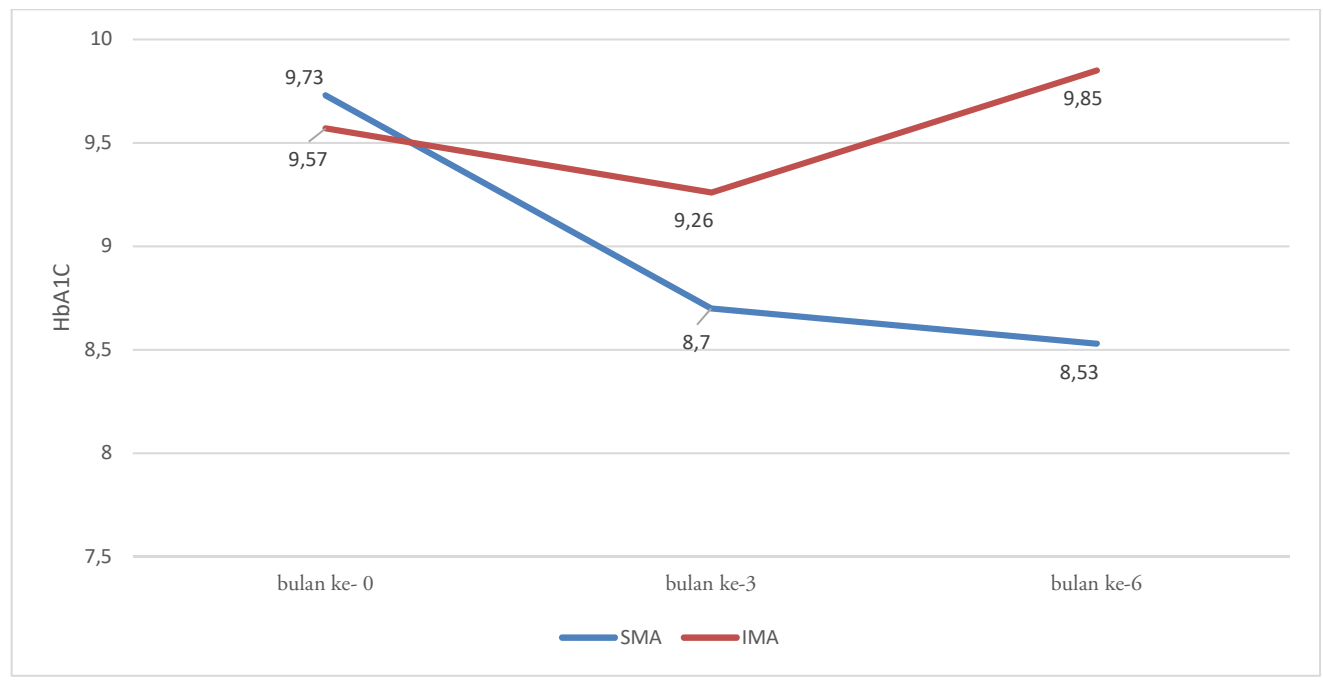

Gambar 1. Trend HbA1C dua kelompok pada 3 kali pengukuran

Tabel 3. Perbandingan rerata HbA1C

\begin{tabular}{|c|c|c|c|c|}
\hline \multirow{2}{*}{ Parameter } & \multicolumn{2}{|c|}{ Rerata HbA1C } & \multirow{2}{*}{ Nilai p } & \multirow{2}{*}{$\begin{array}{c}\text { Perbedaan rerata } \\
\text { (IK95\%) }\end{array}$} \\
\hline & Grup SMA & Grup IMA & & \\
\hline HbA1C bulan ke-0 & $9,73(1,8)$ & $9,57(1,6)$ & 0,774 & $0,16(0,96-1,28)$ \\
\hline HbA1C bulan ke-3 & $8,70(1,3)$ & $9,26(1,1)$ & 0,167 & $0,55(0,24-1,30)$ \\
\hline HbA1C bulan ke-6 & $8,53(0,7)$ & $9,85(1,2)$ & $<0,001$ & $1,32(0,69-1,95)$ \\
\hline
\end{tabular}

Keterangan: Analisis berdasarkan uji t bermakna bila $\mathrm{p}<0,05$

Tabel 4. Perbandingan rerata HbA1C berdasarkan durasi metode SMA

\begin{tabular}{lcccc}
\hline Kelompok & Waktu & Perbedaan rerata HbA1C & Std error & Nilai p \\
\hline SMA & Bulan ke-0 vs Bulan ke-3 & 1,02 & 0,26 & 0,002 \\
& Bulan ke-3 vs Bulan ke-6 & 0,17 & 0,2 & 1,000 \\
\multirow{2}{*}{ IMA } & Bulan ke-0 vs Bulan ke-6 & 1,19 & 0,33 & 0,005 \\
& Bulan ke-0 vs Bulan ke-3 & 0,31 & 0,35 & 1,000 \\
& Bulan ke-3 vs Bulan ke-6 & 0,60 & 0,23 & 0,085 \\
& Bulan ke-0 vs Bulan ke-6 & 0,29 & 0,36 & 1,000 \\
\hline
\end{tabular}

Keterangan: Analisis berdasarkan uji repeated Anova bermakna bila $p<0,05$

sering dijumpai pada anak wanita. ${ }^{1}$ Pada penelitian kami, jumlah subjek berdasarkan jenis kelamin pada kelompok SMAs dan IMA konsisten dengan data beberapa negara yang melaporkan bahwa tidak ada perbedaan. Karakteristik gender ini juga sesuai dengan penelitian Batubara $\mathrm{dkk}^{18}$ bahwa rasio perempuan lakilaki adalah 45:55. Usia saat diagnosis DM ditemukan terbanyak pada kelompok usia 8-12 tahun dengan rerata usia saat diagnosis adalah 8,35 dan 9,07 tahun.
Hal ini berbeda dengan data dari laporan beberapa rumah sakit di Indonesia bahwa puncak insidens DM pada anak didapatkan pada usia 5-6 tahun dan 11 tahun, ${ }^{20}$ sedangkan penelitian Batubara onset DM didapatkan pada usia 7,5 tahun. ${ }^{18}$ Sebagian besar subjek terdiagnosis dalam kondisi ketoasidosis diabetikum (KAD), yaitu 75\% pada kelompok SMAs dan $60 \%$ pada kelompok IMA. Data ini berbeda dengan beberapa penelitian lain. Kejadian KAD saat 
diagnosis paling sedikit di Swedia, yaitu 12,8\%, paling banyak Uni Emirat Arab sejumlah 80\%. ${ }^{21}$ Kejadian KAD berulang juga didapatkan ada 1 subjek yang mengalami KAD tiga kali setelah onset DM dan satu subjek yang mengalami 4 kali KAD. Jumlah KAD saat pertama diagnosis yang banyak terjadi di Indonesia menunjukkan bahwa pengetahuan orang tua dalam mengenali gejala awal DM rendah. Hal ini juga dapat menunjukkan bahwa dokter umum dan dokter spesialis anak di fasilitas kesehatan tingkat pertama kurang terpapar dalam upaya mengenali dan mendiagnosis DM sebelum terjadinya komplikasi akut KAD.

Kontrol metabolik yang baik juga ditentukan oleh regimen insulin yang digunakan, pemantauan gula darah dan pemahaman terhadap tata laksana mandiri DM. Regimen insulin yang digunakan oleh kedua kelompok tidak berbeda yaitu 50\% pada kelompok SMAs dan 60\% pada kelompok IMA menggunakan regimen konvensional split mix sedangkan sisanya $50 \%$ pada kelompok SMAs dan 40\% pada IMA menggunakan regimen basal bolus. Dengan tidak adanya perbedaan regimen insulin pada dua kelompok tersebut maka bias kontrol metabolik sangat minim. Beberapa orang tua subjek juga masih didapatkan pengetahuan yang kurang tentang terapi insulin untuk DM tipe-1 dapat dilihat dari masih adanya riwayat penghentian insulin yang didapatkan pada 3 subjek pada kelompok SMAs dan 1 subjek kelompok IMA. Riwayat pengobatan alternatif juga didapatkan pada 3 subjek kelompok SMAs dan 4 subjek pada kelompok IMA.

Hampir seluruh subjek memiliki alat glukometer dan melakukan pencatatan gula darah harian (19 subjek pada kelompok SMAs dan 17 subjek pada kelompok IMA) walaupun frekuensi pencatatan gula darah harian dilakukan paling sering sejumlah 2 kali perhari, yaitu didapatkan pada 16 subjek di kelompok SMAs dan 13 subjek pada kelompok IMA. Hanya ada 1 subjek pada kelompok SMAs saja yang melakukan pemeriksaan gula darah 3 kali sehari. Sebagai bagian penting keberhasilan manajemen DM tipe-1, ISPAD merekomendasikan pemeriksaan gula darah mandiri sebaiknya adalah 6 kali per hari untuk mencapai kontrol metabolik yang baik. ${ }^{5,10}$ Namun, dengan adanya keterbatasan biaya maka tidak ada seorang subjek pun di kedua kelompok yang melakukan pemeriksaan gula darah harian 6 kali per hari.

Hanya 4 subjek pada kelompok SMAs dan 3 subjek pada kelompok IMA (20\% dan 15\%) yang mempunyai riwayat DM pada orang tua. Hal tersebut sesuai dengan data bahwa sekitar 80\% DM tipe-1 tidak mempunyai riwayat keluarga dengan penyakit serupa. Faktor genetik diakui berperan dalam patogenesis DM tipe-1 yang dikaitkan dengan sistem Human Leukocyte Antigen (HLA) yang berperan sebagai suatu faktor kerentanan pada seorang anak dan bila ada faktor pemicu dari lingkungan (infeksi virus, toksin, dll) baru akan bermanifestasi klinis gejala DM akibat kerusakan sel beta pankreas. ${ }^{1,21}$

Untuk melihat pengaruh metode SMAs yang diterapkan kepada kelompok satu dan dibandingkan dengan kelompok IMA sebagai kontrol maka dilakukan pemeriksaan HbA1C sebagai parameter kontrol metabolik. Pemeriksaan HbA1C merupakan alat yang tepat untuk menilai kontrol glukosa darah jangka lama yang dapat melihat gambaran kadar glukosa darah selama 2-3 bulan sebelumnya. ${ }^{1,5,7}$ Oleh karena itu, pada kedua kelompok dilakukan pemeriksaan kadar HbA1C pada awal penelitian sebagai baseline (bulan ke-0), kemudian untuk mengetahui pengaruh pasca metode SMAs maka dilakukan pemeriksaan ulangan kadar HbA1C pada akhir bulan ke-3 dan ke-6.

Kadar HbA1C pada awal penelitian menunjukkan tidak ada perbedaan rerata $\mathrm{HbA} 1 \mathrm{C}$ antara kelompok SMAs dan IMA $(9,73 \pm 1,8$ vs $9,57 \pm 1,6$ dengan p $>0,774)$. Kemudian pasca metode SMAs, rerata HbA1C bulan ke-3 dan ke-6 menunjukkan perbaikan menjadi $8,7 \pm 1,3$ dan terus menurun menjadi $8,54 \pm 0,7$ pada bulan ke-6. Hasil tersebut lebih baik dibandingkan pada kelompok IMA, yaitu 9,26 $\pm 1,1$ pada bulan ke-3 dan 9,86 $\pm 1,2$ pada bulan ke- 6 . Perbedaan bermakna yang menunjukkan pengaruh metode SMAs dibandingkan IMA didapatkan pada akhir bulan ke-6. Ini berarti bahwa pada akhir bulan ke-6 metode SMAs lebih baik dibandingkan dengan IMA dalam perbaikan kontrol metabolik.

Untuk mengetahui efek SMAs pada kelompok yang sama berdasarkan waktu maka dilakukan uji repeated ANOVA pada masing-masing kelompok. Pada kelompok SMAs menunjukkan adanya perbedaan rerata $\mathrm{HbA} 1 \mathrm{C}$ antara bulan ke-0 dengan bulan ke-3 dan rerata $\mathrm{HbA} 1 \mathrm{C}$ bulan ke-0 dengan bulan ke- 6 . Namun, perbandingan rerata $\mathrm{HbA} 1 \mathrm{C}$ antara bulan ke-3 dengan bulan ke-6 tidak didapatkan perbedaan. Ini menunjukkan bahwa metode SMAs yang dilakukan pada 3 bulan pertama mempunyai pengaruh yang sama baiknya dalam menurunkan kadar HbA1C 
dibandingkan dengan durasi 6 bulan. Hasil ini konsisten dengan penelitian Mejino ${ }^{14}$ di Belanda yang melaporkan bahwa kepuasan dalam menghadiri acara diskusi dalam kelompok SMAs akan menurun setelah durasi 3 bulan. Maka dapat disimpulkan metode SMAs yang dilakukan tiap bulan berturut-turut dalam 3 bulan saja cukup untuk memberikan pengaruh dalam perbaikan HbA1C penderita DM tipe-1. Sementara pada kelompok IMA tidak didapatkan perbedaan antara rerata $\mathrm{HbA} 1 \mathrm{C}$ bulan ke-0 dengan bulan ke-3, bulan ke- 0 dengan bulan ke- 6 , dan bulan ke-3 dengan ke-6.

Keterbatasan penelitian ini adalah masih terdapat perbedaan regimen insulin pada masing-masing kelompok subjek. Jangka waktu yang dilakukan untuk metode SMA hanya 6 bulan sehingga tidak diketahui untuk jangka panjang apakah metode ini akan konsisten memberikan pengaruh yang baik dalam mempertahankan kadar kontrol glukosa. Selain itu, penelitian ini juga tidak memperhitungkan status pendidikan orang tua subjek yang berhubungan dengan pengetahuan tentang tata laksana mandiri DM. Disarankan untuk dilakukan penelitian lebih lanjut dengan menganalisis semua variabel yang memperbaki kontrol metabolik untuk penderita DM tipe-1 sehingga bisa mencapai target $\mathrm{HbA1C}$ yang ideal.

Kesimpulan dari penelitian ini adalah metode SMAs dengan durasi 3 bulan efektif untuk memperbaiki kontrol metabolik penderita DM tipe-1 pada dan remaja walaupun belum mencapai target $\mathrm{HbA} 1 \mathrm{C}$ yang direkomendasikan.

\section{Ucapan terima kasih}

Pengurus Pusat Ikatan Dokter Anak Indonesia dan Frisian Flag Indonesia (subsidiary of Friesland Campina)

\section{Daftar pustaka}

1. Craig ME, Jefferies C, Dabelea D, Balde N, Seth A, Donaghue KC. Definition, epidemiology, and classification of diabetes in children and adolescents. Pediatric Diabetes 2014;15:S4-17.

2. Yati NP, Tridjaja B, penyunting. Pedoman Nasional Pelayanan Kedokteran Diagnosis dan tatalaksana Diabetes Mellitus Tipe 1 pada anak dan remaja. Jakarta: Badan Penerbit IDAI; 2017.

3. Tridjaja B, Yati NP, Faizi M, Marzuki ANS, Moelyo AG, Soesanti F, penyunting. Konsensus nasional pengelolaan diabetes mellitus tipe 1 pada anak dan remaja. Jakarta: Badan Penerbit IDAI; 2015.

4. Donaghue KC, dkk. Microvascular and macrovascular complications in children and adolescents. Pediatric Diabetes 2014;15:S257-69.

5. Lange K, Swift P, Pankowska E, Danne T. Diabetes education in children and adolescents.Pediatric Diabetes 2014;15:S7785 .

6. Kordonuri O, Klingensmith, Knip M, Holl RW, Aansttot HJ, Menon PS, Craig ME. KG. Other complications and diabetes-associated conditions in children and adolescents. Pediatric Diabetes 2014;15: 270-8.

7. Sperling MA, Weinzimer SA, Tamborlane WV, Battelino T, Weinzimer SA, Phillips M. Diabetes mellitus. Dalam: Sperling, penyunting. Pediatic Endocrinology. Edisi ke-4. Philadelphia: Elsevier Saunders; 2014.h.846-99.

8. Dane T, Bangstad HJ, Deeb L, Chobot JP, Mungaie L, Urakami $\mathrm{T}$, dkk. Insulin treatment in children and adolescents with diabetes. Pediatric Diabetes 2014;15:115-34.

9. Smart CE, Annan F, Bruno LPC, Higgins LA, Acerini CL. Nutritional management in children and adolescents with diabetes. Pediatric Diabetes 2014:15 Suppl 2:135-53.

10. Rewers MJ, Pillay K, de Beaufort C, Craig ME, Hanas R, Acerini CL, dkk. Assessment and monitoring of glycemic kontrol in children and adolescents with diabetes. Pediatric Diabetes 2014;15:102-14.

11. Rijswijk C, Zantinge E, Seesing F, Raats I, van Dulmen S. Shared and individual medical appointments for children and adolescents with type 1 diabetes; differences in topics discussed? Patient Education and Counselling 2010;79:351-5.

12. Gutierrez N, Gimpel NE, Dallo FJ, Foster B, Ohagi EJ. Shared medical appointments in a residency clinic: an exploratory study among Hispanic with diabetes. Am J Manag Care 2011;17:e212-4.

13. Egger G, Binns A, Cole MA, Ewald D, Davies L, Meldrum H, dkk. Shared medical appointment: an adjunct for chronic disease management in Australia? Aust Fam Physic 2014;43:151-4.

14. Mejino A, Noordman J, van Dulmen A. Shared medical appointments for children and adolescents with type 1 diabetes: perspectives and experiences of patients, parents, and health care providers. Adoles Health Med Therapeut 2012;3:75-83.

15. Housden L, Wong ST, Dawes M. Effectiveness of group medical visits for improving diabetes care: a systematic review and meta-analysis. CMAJ 2013;185: E635-44.

16. Noffsinger EB, Scott JC. Understanding today's group visit models. Permanente J 2000;4:99-112.

17. Ridge T. Shared medical appointments in diabetes care: A literature review. Diabetes Spectrum 2012;26:72-5.

18. Batubara JRL. Audit of childhood diabetes kontrol in 
Indonesia. Pediatrica Indones 2002;42:280-6.

19. Endyarni B, Batubara JRL, Boediman I. Effect of a structured educational intervention on metabolik kontrol of type 1 diabetes mellitus patient. Paediatrica Indones 2006; 46:260-5.

20. Rustama DS, Subardja D, Oentario C, Pritayati N, Satriono, Harjantien N. Diabetes mellitus. Dalam: Batubara JRL,
Tridjaja B, Pulungan A, penyunting. Buku Ajar Endokrin. Edisi kedua. Jakarta: Badan Penerbit IDAI; 2010.h.120-58.

21. Usher-Smith JA, Thompson M, Ercole A, Walter FM. Variation between countries in the frequency of diabetic ketoacidosis at first presentation of T1D in children: a systematic review. Diabetologia 2012;55:2878-94. 